\title{
Structural Elements and Morphological Characteristics of Pedunculate Oak (Quercus robur L.) in Young Even-Aged Stands of Spačva Forest
}

\author{
Tomislav Dubravac ${ }^{1 *}$, Matej Turk ${ }^{1}$, Robert Licht ${ }^{2}$
}

(1) Croatian Forest Research Institute, Division for Silviculture, Cvjetno naselje 41, HR-10450 Jastrebarsko, Croatia; (2) Croatian Forest Research Institute, Research Centre for Lowland Forests, Trg Josipa Runjanina 10, HR-32100 Vinkovci, Croatia

* Correspondence: e-mail: tomod@sumins.hr

\begin{abstract}
Citation: DUBRAVAC T, TURK M, LICHT R 2017 Structural Elements and Morphological Characteristics of Pedunculate Oak (Quercus robur L.) in Young Even-Aged Stands of Spačva Forest. South-east Eur for 8 (1): 59-66. DOI: https://doi.org/10.15177/seefor.17-09

Received: 3 May 2017; Revised: 14 Jun 2017; Accepted: 16 Jun 2017; Published online: 19 Jun 2017
\end{abstract}

\begin{abstract}
Background and Purpose: Croatian Forest Research Institute and Croatian Forests Ltd., Zagreb, have in 2010 jointly proposed a scientific experiment on permanent experimental plots called "The Impact of the Intensity of Silvicultural Tending on Pedunculate Oak Dieback". The basis for setting up experimental plots were the results of the analysis of surface structure of pedunculate oak (Quercus robur L.) stands of Spačva Forest and its projection area for the next 140 years, and the related issues of regeneration of old and tending of young stands in conditions of increasing climate change. In the future this will present a major problem for forestry practice in silvicultural operations, both in terms of workers and materials.

Materials and Methods: The experiment was conducted in the area of Forest Administration Vinkovci, Forest Office Vinkovci, Management Unit Kunjevci, in three subcompartments of different age (10, 15 and 20 years) where different intensities tending operations of cleaning were conducted. A total of 20 plots were established by using the already established network of silvicultural lines and paths, while the position was recorded by a GPS device. On each plot 30 pedunculate oak trees were permanently marked (600 trees in total). Tree selection was based on spatial and phenotypic criteria.

Results: The initial measurement on permanent experimental plots shows unsatisfactory number of pedunculate oak trees along with the high number of common hornbeam trees. The overall basal area has a tendency of continuous growth in relation to the age of experimental plots. The value of crown length in relation to the total height of pedunculate oak trees is $74.3 \%$ in subcompartment $32 \mathrm{~A}, 53.5 \%$ in subcompartment $34 \mathrm{~A}$, and $54.3 \%$ in subcompartment $38 \mathrm{~A}$. Trunk length, i.e. trunk purity also increases with age; in subcompartment $32 \mathrm{~A}$ on average it amounts to $1.35 \mathrm{~m}$, in subcompartment $34 \mathrm{~A}$ to $3.28 \mathrm{~m}$ and in subcompartment $38 \mathrm{~A}$ to $4.85 \mathrm{~m}$.

Conclusion: After conducting periodic surveys of the established plots by the year 2020 enough data should be collected whose processing, analysis and interpretation would provide guidelines for improving the future management of young pedunculate oak stands.
\end{abstract}

Keywords: silvicultural tending intensities, crown characteristics, young stands, future management

\section{INTRODUCTION}

Morphological characteristics of trees play an important role in trees' defence and adaptation to changing habitat conditions in the context of global climate change. Developed crown indicates a more developed root system $[1,2]$ and therefore a greater degree of adaptation to habitat and climate changes [3]. Vajda [4] determined that in the same habitat conditions the proportion of dead pedunculate oak (Quercus robur L.) trees is smaller in the group with large diameter at breast height and welldeveloped crowns, while Shifley et al. [5] identified the 
social position of trees as one of the significant factors that increase the likelihood of the decline of North American oaks from the red oak group. Dekanić [6] considered the morphological features of pedunculate oak trees to be an extremely important preparatory factor in the complexity of individual tree dieback, while size, diameter increment and basal area increment are a good indicator of its vitality [7-9] and an indicator of habitat change [10].

Previous research shows that in the process of dieback of penduculate oak, trees with larger crowns, i.e. greater assimilation surface, are more resistant, while their crowns become more vital as their increment increases. It is known that in general pedunculate oak trees with underdeveloped crowns are more likely of dieback. One of the main causes of such crown development and intensive dieback is, among other things, the insufficiently intensive thinning which failed to be conducted in young stands. Thinning is known to be a necessary and essential silvicultural operation, while absence of tending in young stands causes a high degree of tree legginess and small reduced broom-like crowns which are not resistant to biotic and abiotic factors. Such crowns indicate small root systems that have difficulties to adapt even to smaller (ten year) oscillations in water-air regime in the soil.
Spačva Forest (Figure 1) comprises of diverse lowland habitats in which forests of pedunculate oak management class occupy $96 \%$ of the total area which amounts to almost 40,000 hectares. This makes it one of the largest coherent complexes of lowland pedunculate oak forests in Europe whose value cannot be measured monetarily because its environmental effect, primarily the anti-erosion and hydrological effect, is much more important than the economic one [11]. Today's oak groves of Spačva are remnants of old-growth forest structures which were mostly clear-cut between 1880 and 1914, reducing the forest cover of Slavonija from $60 \%$ to $35 \%$ [12]. Almost $75 \%$ of Spačva Forest consists of stands older than 80 years [13], while analysis of surface structure of pedunculate oak stands in Spačva Forest and its projection area shows that in the next thirty years regeneration will be very intense and consequently lead to a significant increase of areas with the stands of age-classes I and II.

Bearing in mind these facts and previous research on the structure and dynamics of the harvest of dead and declining pedunculate oak trees in Spačva Forest [14], as well as the dynamics of the decline of pedunculate oak trees depending on phytosociology and age [15], a real problem has appeared in that same areas in terms of financial and

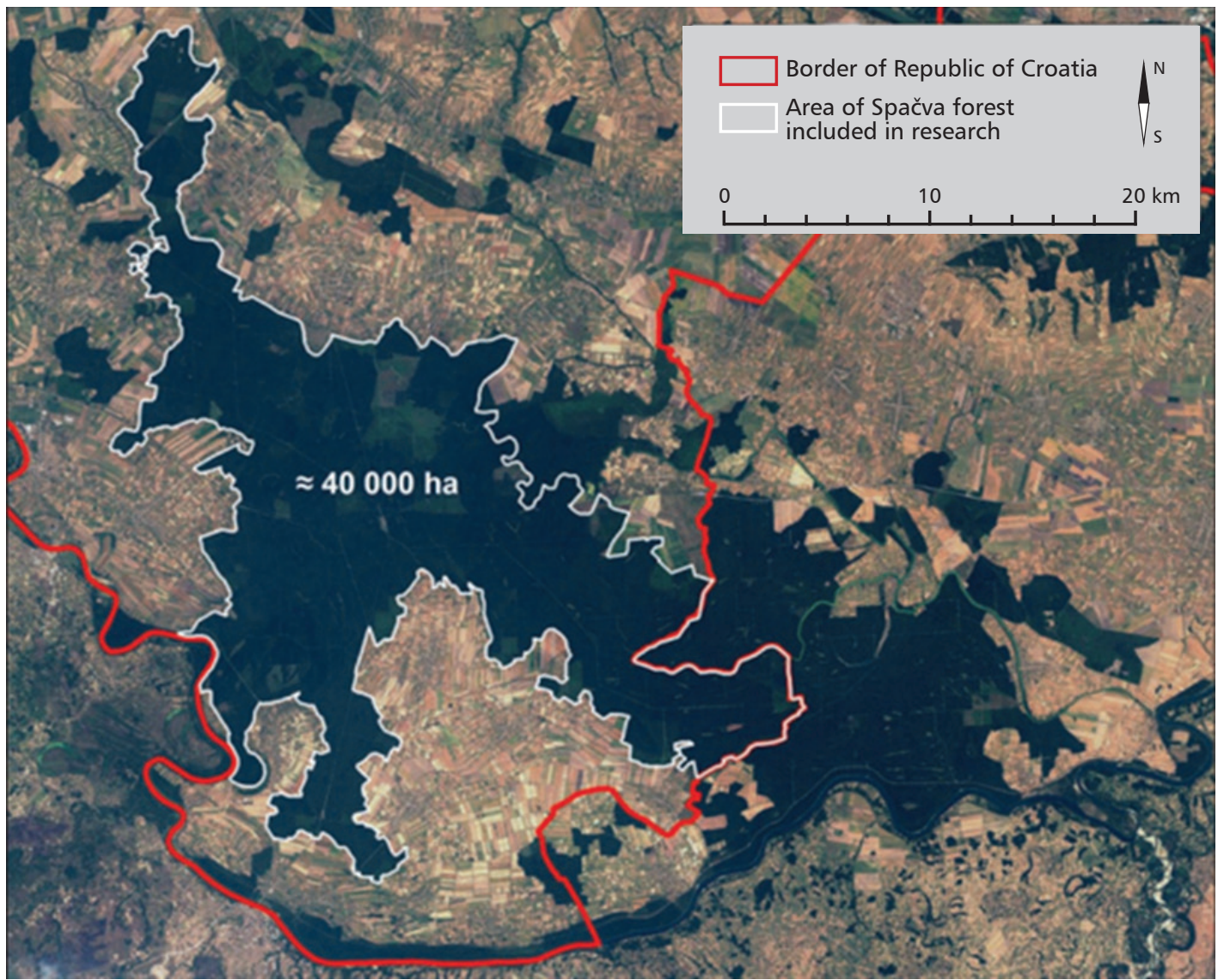

FIGURE 1. "Spačva" forest and investigated area on the LANDSAT satellite image from August 20, 2000. 
human resources and how to carry out all necessary work during both the regeneration phase and tending phase of the stand. Tending operations conducted in young stands are essential to their structure, quality and productivity; the intensity and methods of tending have to be harmonized with natural processes prevalent in the stand and with biological characteristics, environmental requirements and silvicultural traits of the tended species [16].

In light of these findings Croatian Forest Research Institute and Croatian Forests Ltd. Zagreb, in 2010 jointly proposed a scientific experiment on permanent experimental plots called "The Impact of the Intensity of Silvicultural Tending on Pedunculate Oak Dieback". The experiment was conducted in the area of Forest Administration Vinkovci, Forest Office Vinkovci, Management Unit Kunjevci.

Since very little research has been done on the morphology of young even-aged stands of pedunculate oak both in Croatia and globally, and since there is little data available in the literature, except on the features of growth and the development of crowns in the youngest stands of age-classes I, II and III [17-20], the purpose of this article is to contribute to the knowledge about those values. Therefore, along with other data on this study, the article includes rarely measured and published data on tree crown radius, first branch height and other features, all with the aim of better knowledge and understanding of relations within young pedunculate oak stands.

\section{MATERIALS AND METHODS}

The process of creating surface structure projection area started with the analysis of data from the management plan. Based on the management plan data 13 management units with predominant pedunculate oak management class were selected, covering the area of Spačva Forest managed by Forest Administration Vinkovci (Table 1), and were then used for further analyses.
The results from the data analysis were used for creating surface structure projection area for the studied management units for the period of the next 140 years (2011-2150) (Figure 2).

This projection has shown that with current methods of natural regeneration of pedunculate oak stands under the crown canopy of old trees already by the year 2020 the surface area of young stands is expected to increase; the area of the age-class I will reach maximum value in 2044 on a total of 18,000 ha or $43 \%$ of the studied area, while the surface of age-classes I + II will reach maximum value in 2050 on a total of 27,000 ha or $64 \%$ of the studied area.

As part of the project "The Impact of the Intensity of Silvicultural Tending on Pedunculate Oak Dieback" 20 permanent experimental plots were established in the area of Forest Administration Vinkovci, Forest Office Vinkovci,

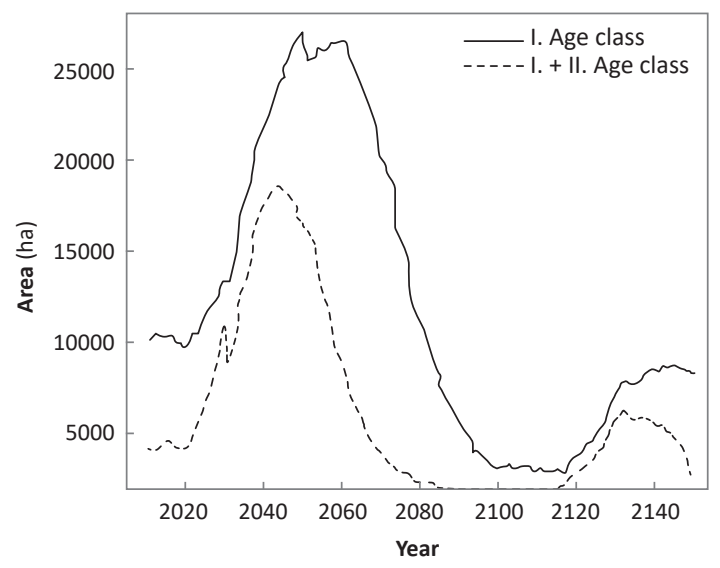

FIGURE 2. Graphical overview of trending projection of I. and II. age class for the next 140 years

TABLE 1. List of managment units and number of subcompartments for pedunculate oak managment class used for analysis

\begin{tabular}{|c|c|c|c|c|}
\hline No & Managment unit & $\begin{array}{l}\text { Managment plan } \\
\text { (starting year) }\end{array}$ & $\begin{array}{c}\text { Number of } \\
\text { subcompartments }\end{array}$ & $\begin{array}{r}\text { Area } \\
\text { (ha) }\end{array}$ \\
\hline 1 & Ceranski lugovi & 2001 & 113 & 2064.92 \\
\hline 2 & Debrinja & 2007 & 234 & 4551.87 \\
\hline 3 & Desićevo & 2007 & 160 & 2082.85 \\
\hline 4 & Dubovica & 2002 & 43 & 809.46 \\
\hline 5 & Kragujna & 2003 & 256 & 3310.11 \\
\hline 6 & Kunjevci & 2002 & 169 & 2731.44 \\
\hline 7 & Kusare & 2003 & 120 & 2707.73 \\
\hline 8 & Naračke & 2003 & 82 & 1577.88 \\
\hline 9 & Otočke šume & 2001 & 110 & 2413.36 \\
\hline 10 & Slavir & 2004 & 434 & 7858.32 \\
\hline 11 & Topolovac & 2002 & 121 & 3208.66 \\
\hline 12 & Trizlovi-Rastovo & 2007 & 133 & 1809.72 \\
\hline \multirow[t]{2}{*}{13} & Vrbanjske šume & 2005 & 600 & 7569.98 \\
\hline & Total & & 2575 & 42696.30 \\
\hline
\end{tabular}


Management Unit Kunjevci, in subcompartments 32A, $34 \mathrm{~A}$ and $38 \mathrm{~A}$ (Figure 3 ). All the plots were established in a typical pedunculate oak-hornbeam forest (Carpino betuliQuercetum roboris typicum Rauš 1971).

Preliminary selection of experimental plot locations in each subcompartment was made by terrain reconnaissance along with the digital terrain model created for the purpose of removing the effect of the microrelief. First the plots were temporarily staked out by using the already established network of silvicultural lines and paths and their position was recorded with a GPS device. After importing the preliminary locations of plots into the ArcMap program, the plots were arranged so that all plots are within $50 \mathrm{~cm}$ of the altitude range of the terrain. The final locations of plots were permanently marked by wooden stakes containing repetition marks and the number of the plot (Figure 4). The size of each of the 20 staked out plots is $33 \times 35 \mathrm{~m}$ (Figure 5). The area of each plot is 0.12 ha (Table 2).

On each plot, 30 pedunculate oak trees were permanently marked with orange plastic tags for log classification (Figure 6). In total 600 trees were marked. The selection of trees was done according to the phenotypic and spatial criteria. Phenotypically best trees were chosen which are completely healthy and without noticeable damage (mechanical, game damage, barkpeeling damage, bitten off shoots). The trunks of those trees had to be of good quality (straight, without rowlocks or thick branches), while the trees had to be the highest in the vertical structure. They also had to be grown from seeds and had to have well-developed crowns (crown tops in the upper third of the crowns). The older trees that represented pre-growth were not selected. By using the spatial criterion 10 pedunculate oak trees, evenly distributed on the surface with triangular spacing between the selected trees, were chosen on each line. Depending on the field conditions the distance was 2-3 meters.

In each subcompartment two repetitions composed of three experimental plots called "Standard practice", "Treatment" and "Control" were set up, with the exception of subcompartment 32A in which an additional plot called "Reduction" was set up as well.

On "Standard practice" plots, procedures in accordance with current standards in practice were carried out. In this process it is assumed that the number of oak tree trees was not reduced or that it was reduced only minimally.

On "Treatment" plots the number of oak tree trees was reduced to about 1000 future trees per ha with spacing

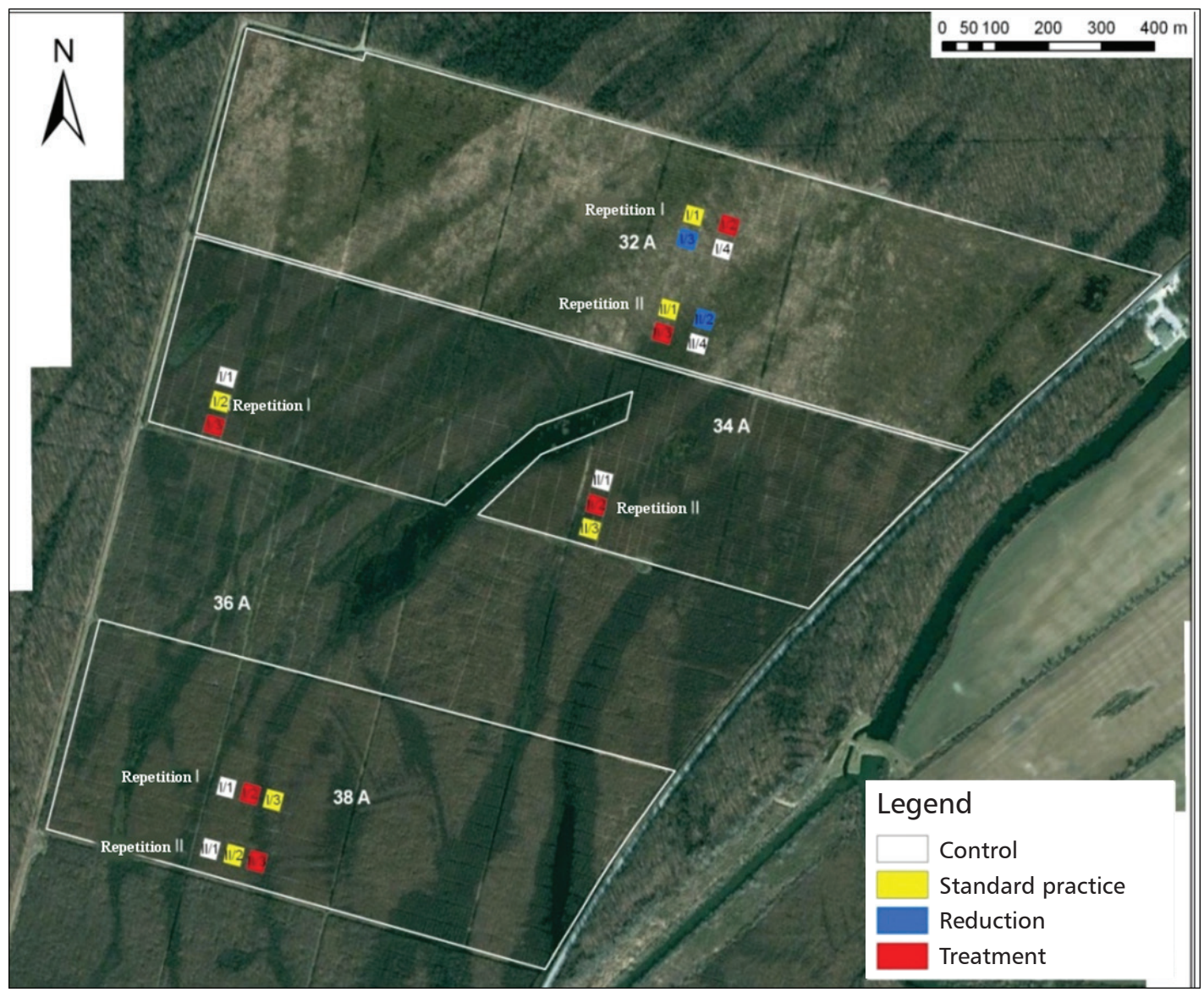

FIGURE 3. Location of permanent experimental plots 
TABLE 2. Basic information about subcompartments in which experimental plots are established.

\begin{tabular}{|c|c|c|c|c|c|c|c|c|}
\hline \multirow{2}{*}{ Subcompartment } & \multirow{2}{*}{$\begin{array}{l}\text { Stand age* } \\
\text { (year) }\end{array}$} & \multirow{2}{*}{$\begin{array}{l}\text { Area } \\
\text { (ha) }\end{array}$} & \multicolumn{3}{|c|}{$\begin{array}{c}\text { Number of } \\
\text { experimental plots }\end{array}$} & \multicolumn{3}{|c|}{$\begin{array}{l}\text { Area of experimental plots } \\
\text { (ha) }\end{array}$} \\
\hline & & & Control & Treatment & Total & Control & Treatment & Total \\
\hline $32 \mathrm{~A}$ & 10 & 65.11 & 2 & 6 & 8 & 0.24 & 0.72 & 0.96 \\
\hline $34 \mathrm{~A}$ & 16 & 46.13 & 2 & 4 & 6 & 0.24 & 0.48 & 0.72 \\
\hline $38 \mathrm{~A}$ & 21 & 41.14 & 2 & 4 & 6 & 0.24 & 0.48 & 0.72 \\
\hline Total & & & 6 & 14 & 20 & 0.72 & 1.68 & 2.4 \\
\hline
\end{tabular}

*Stand age during initial measurement in 2011

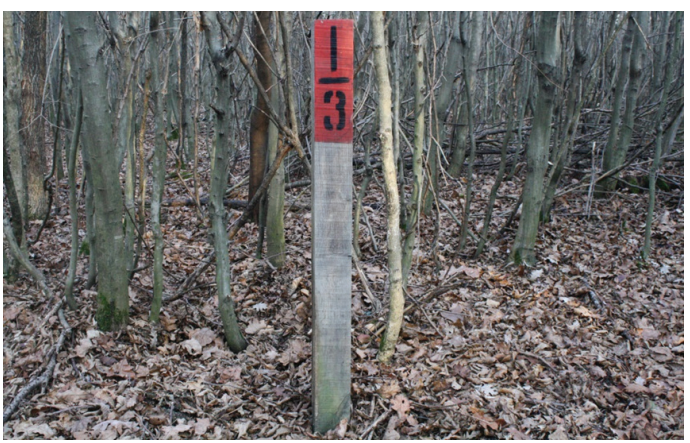

FIGURE 4. Marking of the location of permanent plots

between the selected trees of 2.5 to $3 \mathrm{~m}$. Cleaning was conducted only around marked trees, thus removing all the trees that impeded their growth, including pedunculate oak trees.

On "Control" plots no treatment was conducted and the plots were left to develop naturally. The measured values will be used for comparison with other plots.

In subcompartment 32A the "Reduction" plot was established on which high quality pedunculate oak trees were left with spacing of about $1.5 \mathrm{~m}$, while all competitors were removed by cleaning, carried out on the entire surface of the line. All other pedunculate oak trees were removed, regardless of whether or not they obstructed the selected trees.

After the establishment and marking of permanent experimental plots, the selection of future trees and the conducted cleaning, measurements were carried out. The measurements were carried out in the spring of 2011. On each of the three inner lines two cross-sectional diameters at breast height, trunk length (height of the beginning of the crown), the height of the widest part of the crown, two crown radius and the total height of the tree were measured on marked pedunculate oak trees.

On two subplots of $5 \times 5 \mathrm{~m}$ in size, the total measurement of trees was conducted by tree calliper gauge millimetre. Heights (with a bar for measuring height in $\mathrm{cm}$ ) and diameters at breast height were also measured on the subsample of pedunculate oak and common hornbeam trees for the purpose of creating height curves. The diameter of trees which did not outgrow their breast height was measured at the half of tree height $(0.5 \mathrm{H})$.

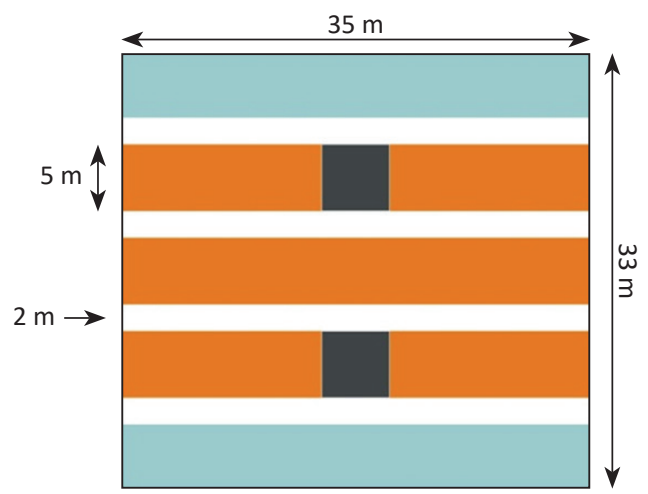

$\square$ Border of experimental plot $\square$ Lines $(5 \times 35 \mathrm{~m})$

Lines in which 10 pedunculate oak trees are marked for a detailed measurment

FIGURE 5. Structure of permanent experimental plot

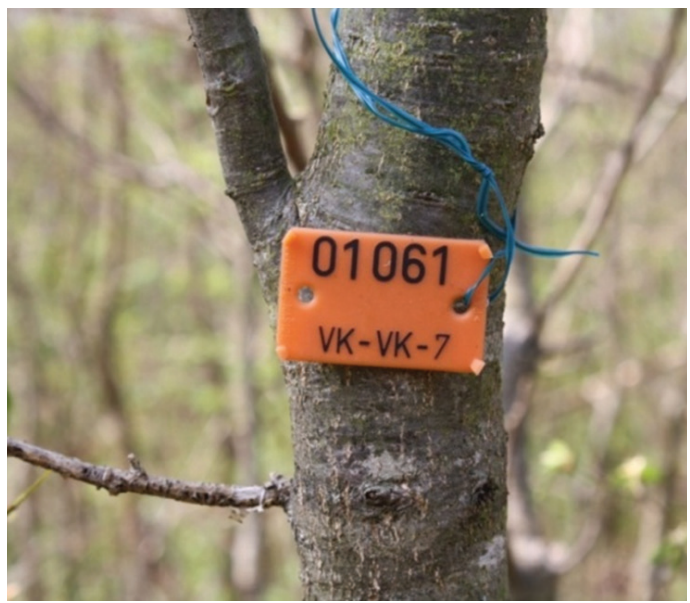

FIGURE 6. Marking future trees of pedunculate oak

The obtained data were analysed using Microsoft Office 2010 package and STATISTICA 7.1 [21]. In order to eliminate the impact of outliers and extreme values the median was taken as the mean value. 


\section{RESULTS WITH DISCUSSION}

The analysis and processing of filed data provided basic elements of the structure which are shown in Tables 3 and 4 which offer interesting conclusions.

The number of pedunculate oak trees as compared to hornbeam (Table 3 ) is not optimal; in young stands of pedunculate oak and common hornbeam (3-10 years) the total number of plants ranges from 35,000 to 40,000 per ha, out of which pedunculate oak trees should amount to 24,000-32,000 trees per ha and common hornbeam to about 18,000 trees per ha, along with other accompanying plant species [22].

Novotny et al. [23] have found that for the middle of first age-class there are 2175 trees per ha of pedunculate oak with a basal area of $9.47 \mathrm{~m}^{2} \cdot \mathrm{ha}^{-1}, 2850$ trees per ha of common hornbeam with a basal area of $8.23 \mathrm{~m}^{2} \cdot \mathrm{ha}^{-1}$ (in total 5750 trees per ha and $20.34 \mathrm{~m}^{2} \cdot \mathrm{ha}^{-1}$ ), while according to the guidelines for creating ecological-management types [24] in the first age-class there are 3495 trees per ha of pedunculate oak with a basal area of $9.4 \mathrm{~m}^{2} \cdot \mathrm{ha}^{-1}$, and 2460 trees per ha of common hornbeam with a basal area of $4.9 \mathrm{~m}^{2} \cdot \mathrm{ha}^{-1}$ (in total 5955 trees per ha and $14.3 \mathrm{~m}^{2} \cdot \mathrm{ha}^{-1}$ ). If we compare this data with the results from Table 3 , we can clearly see big difference which indicates a significantly disrupted natural structure according to the number of pedunculate oak trees and their basal area. The situation is in a way satisfactory in subcompartment $32 \mathrm{~A}$, while in subcompartments $34 \mathrm{~A}$ and $38 \mathrm{~A}$ the values are above the optimum. Such results show the problematic future of these stands in terms of their stability and productivity.

The value of the crown length in relation to the total height of pedunculate oak trees in subcompartment 32A is $74.3 \%$, in $34 \mathrm{~A} 53.5 \%$ and in $38 \mathrm{~A} 54.3 \%$. These values are higher than the results of previous research; Dubravac [25] and Hren and Krejči [26] determined the value of crown length to be $45 \%$ of the total tree height.

Figure 7 represents a box-and-whisker chart. Based on this figure, while taking into account the subcompartment age, it can be concluded that trunk length, i.e. trunk purity increases with age; in subcompartment $32 \mathrm{~A}$ its average value is $1.35 \mathrm{~m}$, in $34 \mathrm{~A} 3.28 \mathrm{~m}$ and in $38 \mathrm{~A} 4.85 \mathrm{~m}$.

Crown length of the tree also increases with age (Figure 8). The mean values range from $2.78 \mathrm{~m}$ in subcompartment $32 \mathrm{~A}$ to $5.66 \mathrm{~m}$ in subcompartment 38A. Dubravac [19] stated that the crown length of the age-class I amounts to $2.93 \mathrm{~cm}$, but it should be emphasized that this referred a small sample (1 experimental plot, 18 trees). The same author [18], also on

TABLE 3. Number of trees and basal area in researched area

\begin{tabular}{|c|c|c|c|c|c|c|c|c|}
\hline \multirow[b]{2}{*}{ Subcompartment } & \multirow[b]{2}{*}{$\begin{array}{l}\text { Stand age* } \\
\text { (year) }\end{array}$} & \multirow[b]{2}{*}{$\begin{array}{l}\text { Area } \\
\text { (ha) }\end{array}$} & \multicolumn{2}{|c|}{ Pedunculate oak } & \multicolumn{2}{|c|}{ Common hornbeam } & \multicolumn{2}{|c|}{ Overall } \\
\hline & & & $\underset{\text { (trees }}{\mathbf{N}}$ ha $^{-1}$ ) & $\begin{array}{c}\mathbf{G} \\
\left(\mathrm{m}^{2} \cdot \mathrm{ha}^{-1}\right)\end{array}$ & $\underset{\text { (trees }}{\mathbf{N}}$ ha $^{-1}$ ) & $\begin{array}{c}\mathbf{G} \\
\left(\mathrm{m}^{2} \cdot \mathrm{ha}^{-1}\right)\end{array}$ & $\underset{\text { (trees:ha }}{\mathbf{N}}$ & $\begin{array}{c}\mathbf{G} \\
\left(\mathrm{m}^{2} \cdot \mathrm{ha}^{-1}\right)\end{array}$ \\
\hline $32 \mathrm{~A}$ & 10 & 65.11 & 25452 & 6.23 & 21050 & 3.56 & 49875 & 9.79 \\
\hline $34 \mathrm{~A}$ & 16 & 46.13 & 2733 & 3.79 & 77900 & 20.89 & 85633 & 24.59 \\
\hline $38 \mathrm{~A}$ & 21 & 41.14 & 1833 & 10.37 & 23067 & 18.39 & 30667 & 28.76 \\
\hline
\end{tabular}

*Stand age during initial measurement in 2011

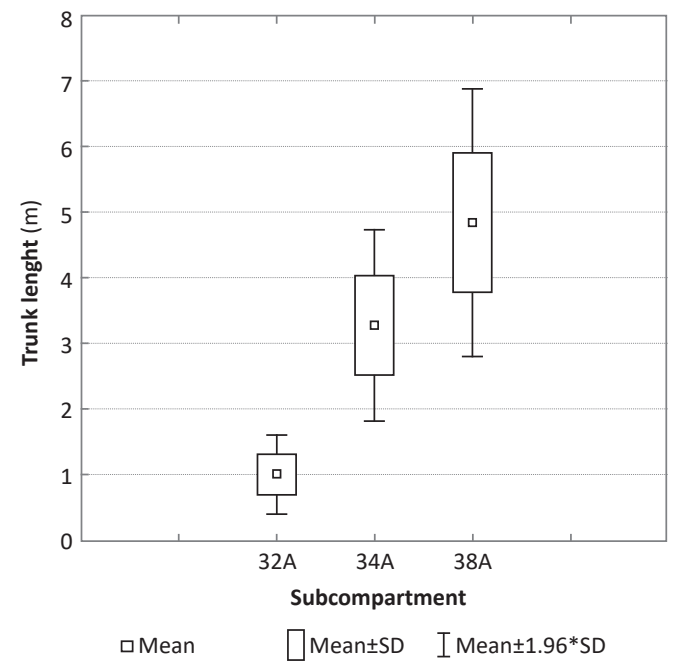

FIGURE 7. Trunk length of pedunculate oak in 3 subcompartments $(n=600)$

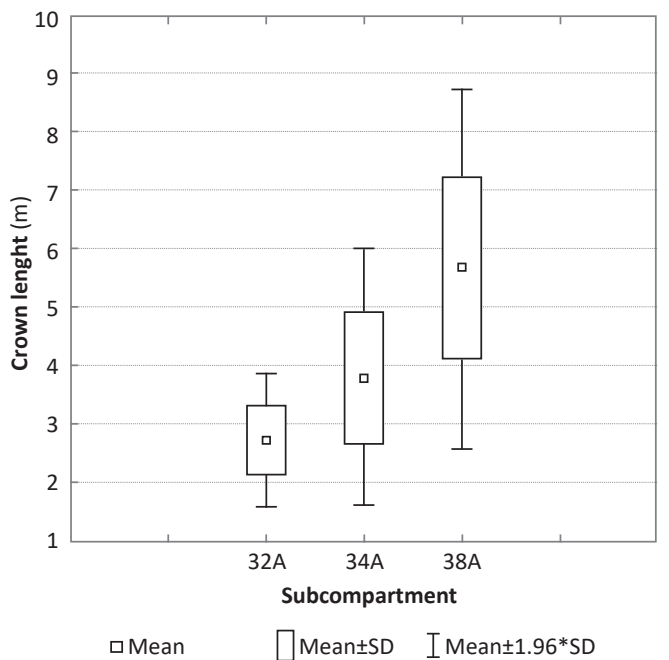

FIGURE 8. Crown length of pedunculate oak in 3 subcompartments $(n=600)$ 
TABLE 4. Morphological traits of pedunculate oak for researched area

\begin{tabular}{cccccccc}
\hline Subcompartment & $\begin{array}{c}\text { Stand age* } \\
(\text { year })\end{array}$ & $\begin{array}{c}\text { Mean diameter at } \\
\text { breast height }(\mathrm{cm})\end{array}$ & $\begin{array}{c}\text { Total height } \\
(\mathrm{m})\end{array}$ & $\begin{array}{c}\text { Trunk lenght } \\
(\mathrm{m})\end{array}$ & $\begin{array}{c}\text { Mean crown } \\
\text { radius } \\
(\mathrm{m})\end{array}$ & $\begin{array}{c}\text { Crown lenght } \\
(\mathrm{m})\end{array}$ \\
\hline $32 \mathrm{~A}$ & 10 & 2.86 & 3.74 & 1.35 & 0.86 & 2.78 \\
34A & 16 & 5.73 & 7.08 & 3.28 & 1.07 & 3.79 \\
38A & 21 & 9.3 & 10.43 & 4.85 & 1.30 & 5.66 \\
\hline
\end{tabular}

*Stand age during initial measurement in 2011

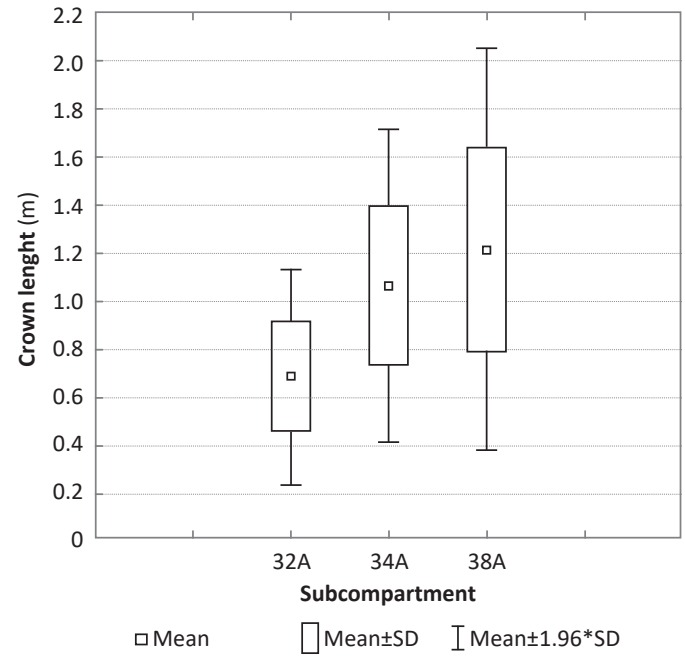

FIGURE 9. Crown radius of pedunculate oak in 3 subcompartments $(n=600)$

the sample of one experimental plot, determined the mean value of $1.39 \mathrm{~m}$ for crown radius in the age-class I. In our research (Figure 9) the values for crown radius are $0.73 \mathrm{~m}$ for subcompartment 32A, $1.07 \mathrm{~m}$ for $36 \mathrm{~A}$ and $1.30 \mathrm{~m}$ for 38A.

From the created height curves (Figure 10) it is apparent that the height gain is intense and that the curve shifts "up and to the right". At the time of intensive height growth of the even-aged stands, a significant shift of the height curve is achieved [16], and comparison of the height curves for subcompartment 34A and 38A shows that in the older stand the trees of the same diameters have a higher height. Also, there is greater diameter dispersion with the increase of the stand's age.

\section{CONCLUSION}

The initial measurement on permanent experimental plots shows unsatisfactory number of pedunculate oak trees along with the high number of common hornbeam trees, which is in direct link with improper implementation of tending, thus endangering the future and the stability of these stands.

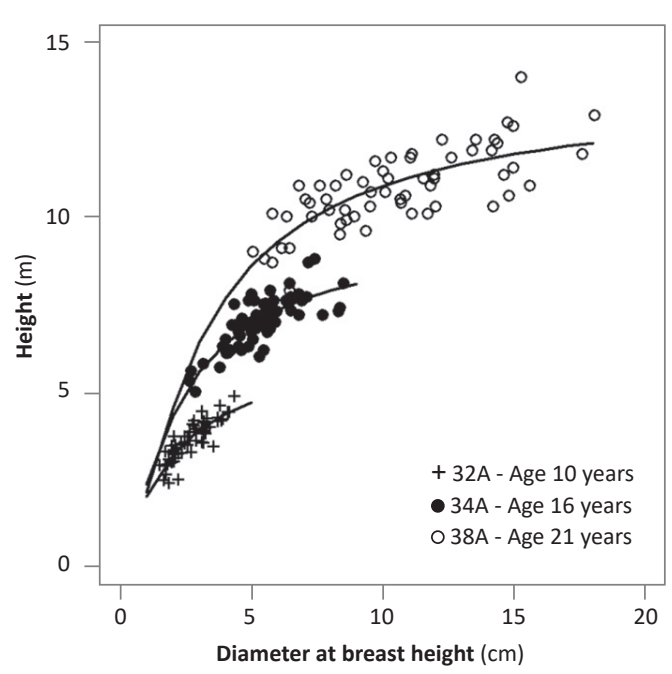

FIGURE 10. Height curve of pedunculate oak in 3 subcompartments of different age ( $n=180$ model trees)

The overall basal area has a tendency of continuous growth in relation to the age of experimental plots. The initial increase is large, from $9.79 \mathrm{~m}^{2}$.ha-1 to 24.59 , followed by a significant increase in the number of trees and an increase in diameter at breast height. The increase is then reduced, amounting to $28.76 \mathrm{~m}^{2} \cdot \mathrm{ha}^{-1}$ on the oldest experimental plot with a significant reduction in the number of trees and the increase in diameter at breast height.

Trunk purity of young pedunculate oak trees was measured from the ground to the first branch height and is expressed in meters. Based on the measured data it can be concluded that with the increase in age the height at which the first branches appear also increases. In other words, trunk purity increases with age, therefore amounting to an average of $1.35 \mathrm{~m}$ on the youngest experimental plot, while on the oldest plot it amounts to an average of $4.85 \mathrm{~m}$.

After conducting periodic surveys of the established plots by the year 2020 a sufficient amount of data should be collected whose processing, analysis and interpretation would provide guidelines for improving the future management of young pedunculate oak stands. 


\section{REFERENCES}

1. ČERMÁK J, PRAX A 2001 Water balance of the floodplain forests in southern Moravia considering rooted and rootfree compartments under contrasting water supply and its ecological consequences. Ann For Sci 58 (1): 1-12

2. TATARINOV F, URBAN J, ČERMÁK J 2008 The application of "clump technique" for root system studies of Quercus robur $\mathrm{L}$. and Fraxinus excelsior L. Forest Ecol Manag 255 (3-4): 495-505. DOI: https://doi.org/10.1016/i.foreco.2007.09.022

3. WARGO M 1996 Consequences of environmental stress on oak: predisposition to pathogens. Ann Sci Forest 53 (2-3): 359-368

4. VAJDA Z 1968 Scientific research studies on drying oak forests. Sumar list 92 (3-4): 122-142

5. SHIFLEY SR, FAN Z, KABRICK JM, JENSEN RG 2006 Oak mortality risk factors and mortality estimation. Forest Ecol Manag 229 (13): 16-26. DOI: https://doi.org/10.1016/i.foreco.2006.03.033

6. DEKANIĆ S 2014 Morphological and dendrochronological analysis of damaged pedunculate oak trees (Quercus robur L.) in old stands of the Spačva forest (in Croatian with English summary). PhD thesis, University of Zagreb, Faculty of Forestry, Zagreb, Croatia, $258 \mathrm{p}$

7. PEDERSEN BS 1998 The role of stress in the mortality of midwestern oaks as indicated by growth prior to death. Ecology 79 (1): 79-93. DOI: https://doi.org/10.1890/00129658(1998)079[0079:TROSIT]2.0.CO;2

8. BIGLER C, BUGMANN H 2004 Assessing the performance of theoretical and empirical tree mortality models using tree-ring series of Norway spruce. Ecol Model 174 (3): 225-239. DOI: https://doi.org/10.1016/j.ecolmodel.2003.09.025

9. PEET R, CHRISTENSEN N 1987 Competition and Tree Death. BioScience 37 (8) 586-595. DOI: https://doi. org $/ 10.2307 / 1310669$

10. PRANJIĆ A, LUKIĆ N 1989 The increment of pedunculate oak trees as an indicator of environmental changes (in Croatian with English summary). Glas šum pokuse 25: 79-94

11. KLEPAC D 1996 Old forests of pedunculated oak and their contribution to development of Croatia (in Croatian with English summary). Proceedings of HAZU, Science research center Vinkovci and Hrvatske šume, pp 13-26

12. VUKELIĆ J, RAUŠ Đ 1998 Forest fitocenology and forest communities in Croatia. University of Zagreb, Faculty of Forestry, Zagreb, Croatia, $310 \mathrm{p}$

13. GRGLJANIĆ J, GREGOROVIĆ I 2003 Age structure of pedunculate oak in Spačva. In: Klepac D, Čorkalo Jemrić K (ed) A Retrospective and perspective of managing forests of pedunculate oak in Croatia. Croatian Academy for Science and Arts, Zagreb, Croatia,, pp 95-108

14. DUBRAVAC T, DEKANIĆ S 2009 Structure and dynamics of the harvest of dead and declining trees of pedunculate oak in the stands of Spačva forest from 1996 to 2006 (in Croatian with English summary). Sumar list 133 (7-8): 391-405
15. DEKANIĆ S, DUBRAVAC T, PILAŠ I, INDIR K 2009 Dynamics of the decline of pedunculate oak trees in the stands of Spačva forest from 1996 to 2006 depending on phytosociology and age (in Croatian). Proceedings of the Croatian Academy for Science and Arts, Zagreb, Croatia

16. ANIĆ । 2007 Silviculture 1. Internal script (in Croatian), University of Zagreb, Faculty of Forestry, Zagreb, Croatia, $97 \mathrm{p}$

17. DUBRAVAC T 2002 Regularity of growth of crown structures of peduncled oak and common hornbeam depending on $\mathrm{dbh}$ and age in Carpino betuli-Quercetum roboris Anić ex Rauš 1969 community (in Croatian with English summary). PhD thesis, University of Zagreb, Faculty of Forestry, Zagreb, Croatia, $196 \mathrm{p}$

18. DUBRAVAC T 2003 Developmental dynamics of crown diameters in pedunculed oak and common hornbeam related to diameter breast height and age (in Croatian with English summary). Rad Šumar Ins Jastrebar 38 (1): 35-54

19. DUBRAVAC T 2004 Developmental dynamics of crown lenght in pedunculed oak and common hornbeam related to diameter breast height and age (in Croatian with English summary). Rad Šumar Ins Jastrebar 39 (1): 37-51

20. KREJČI V 1988 Increment of crown diameter for pedunculate in Genisto elatae - Quercetum roboris Horv. 1938 in Croatia (in Croatian with English summary). Master thesis,. University of Zagreb, Faculty of Forestry, Zagreb, Croatia, $60 p$

21. STATSOFT, INC.2006 STATISTICA (data analysis software system), version 7.

22. MATIĆ S 1993 Sufficient number of young trees is the most significant condition for proper regeneration, growth and care of major tree species (in Croatian with English summary). Ann Exper Silv (pecial issue) 4: 365-380

23. NOVOTNY V, DUBRAVAC T, SELETKOVIĆ A, INDIR K 2006 Research of diameter structure of peduncled oak and common hornbeam (Carpino betuli-Quercetum roboris Anić ex. Rauš 1969.) (in Croatian with English summary). Rad Šumar inst Jastrebar (special issue) 9: 263-278

24. BEZAK K, CESTAR D, HREN V, KOVAČEVIĆ Z, MARTINOVIĆ J, PELCER Z 1989 Uputstvo za izradu karte ekološko-gospodarskih tipova brdskog i nizinskog područja (II) SR Hrvatske (in Croatian). Rad Šumar Ins Jastreb 79: 1-119

25. DUBRAVAC T 1998 Investigation of the structure of the crowns of pedunculated oak and common hornbeam in a community Carpino betuli - Quercetum roboris / Anić 1959 / Rauš 1969 (in Croatian with English summary). Rad Šumar Inst Jastreb 33 (2): 61-72

26. HREN V, KREJČI V 1990 Shift of crown lenght curve in even-aged english oak stands regarding their age (in Croatian with English summary). Rad Šumar Inst Jastreb 25 (2): 337-344 